\title{
Capital Reconstruction and Capital Accumulation in Berlin: A Reply to Peter Marcuse
}

\author{
SCOTT CAMPBELL
}

In a recent issue of this journal, Peter Marcuse (1998) strongly criticizes the current reconstruction of Berlin as the new German capital. Marcuse joins a growing number of prominent intellectuals and politicians in speaking out against a massive Holocaust memorial proposed for the center of Berlin, expressing the impossibility of representing and explaining a monstrous historical period through an abstract design of sculpture and landscape architecture. Yet Marcuse does not simply question the architectural elements of proposed monuments, government buildings and high-profile commercial buildings. Instead, he raises a more fundamental objection: that this very preoccupation with symbolic architectural forms is obscuring a more important debate about the reconcentration of political and economic power in the German capital. Marcuse's most provocative contention is to claim parallels between prewar and contemporary Berlin: that the current concentration of government and large corporations in Berlin has similarities to the preconditions that led to the abuse of this power in the 1930s. Marcuse remains the skeptic, not embracing a more popular rhetoric that the opening of the wall in 1989 has created Berlin's first real opportunity to lead a stable, democratic nation.

The current preoccupation in Berlin with architectural debates is not unexpected. Germans are self-conscious about how outsiders view their capital city, architecture and monuments. They realize that there is an enduring mistrust of Germany's dealing with the past, a suspicion that its efforts to transform its history are in fact efforts to minimize or marginalize past German guilt. Unlike monuments in Washington or Jerusalem, there is a complex need in Berlin to 'express shame as well as sorrow' (Wise, 1998: 148), and to reconcile the representation of both victims and perpetrators. At the center of this debate is the current controversy surrounding the plan to erect a massive Holocaust memorial (Mahnmal) just south of the Brandenburg Gate, which has been front page news for many months and years in Berlin.

This preoccupation with symbolism could suggest that the Germans, and especially Berliners, are particularly adept at understanding their political and historical identities through their architecture and monuments. However, Marcuse contends that this preoccupation might have the opposite effect. He argues that the current German fixation on aesthetics has obscured the troubling transformation of Berlin into a concentrated center of political and economic power. And for Marcuse, who emigrated from Berlin with his family at the age of four when Hitler came to power, this contemporary reconcentration of power in the German capital seems to be an especially unsettling reoccurrence. 
In this light, Marcuse argues that the planned Holocaust memorial will not represent a heightened awareness of Germany's historical responsibility, but instead its marginalization, both spatially and politically. This aesthetic repackaging of German history isolates and sanitizes its troublesome past. Ostensibly acknowledging and confronting the past, the monument actually insures that the nation's past does not interfere with the contemporary accumulation of power and wealth. The real symbols of Marcuse's modern Berlin, rather than the commissioned artworks and isolated monuments, are the new government bureaucratic fortresses, the proposed Bannmeile (protest-free zone) around these fortresses, the corporate high-rises under construction, the massive new infrastructure works, and the gentrification of East Berlin streets into exclusive boulevards of consumption. Though provocative and a rich source of intellectual debate, the aesthetics of development distracts from the underlying question of power. (In the language of the former East Germany, the cultural superstructure remains subservient to the base.) 'The issues are power and its uses, wealth and its uses; framing the debate as one about form trivializes the issues, trivializes the history, serves to distract attention (perhaps deliberately?) from the underlying decisions' (Marcuse, 1998: 334).

Marcuse's wariness about Germany's treatment of the past comes at a time of tremendous new construction and economic hype in Berlin, as the city prepares for the return next year of both the national government and hopefully an economic boom as well. Despite the ongoing economic recession, high unemployment and fiscal crisis, Berlin boosters talk about the metropolis reemerging as a high-tech, information-oriented global city that opens up eastern markets. Boosterism and critical skepticism are diametrically opposite responses to urban economic development strategies. If much of the current writing about post-unification Berlin comes from the boosteristic camp, Peter Marcuse refuses to join in the collective euphoria about the once-divided and struggling city that is now 'Europe's largest construction site'. He instead decries the city's appropriation by big capital.

Against this backdrop of speculative office construction and government building renovations is the ongoing controversy over the design and construction of a Holocaust memorial. First proposed in 1988, the memorial idea took on greater significance after the wall came down a year later and Berlin was picked as the future German capital in 1991. As a monument in the capital, rather than in a provincial city, it would represent a German national interpretation of the Holocaust. Consequently, the memorial has emerged as the latest lightning-rod in the ongoing debate about German history and national identity - a role that the capital city debate (between Berlin and Bonn) had played in 1990-91.

The national government donated a huge plot of land, just south of the Brandenburg Gate and north of Potsdamer Platz, in the heart of the new Berlin (and not far from the Reichstag and the ruins of the Gestapo Headquarters). The choice of a site so massive and central seemed designed to inoculate the German government from accusations that it was neglecting the Holocaust. ${ }^{1}$

Early on the proposal faced criticism, including from the directors of museums in former concentration camps, who argued that financial resources would be better used to maintain these actual sites of Nazi crimes than to build an abstract memorial on a new site. Others charged that the site would become merely a 'wreath dumping place' for sanitized ceremony, rather than a real confrontation with the past (Wise, 1998: 148). A

1 Some have seen the Holocaust memorial, and its emphasis on Jewish victims of the Holocaust, as a 'compensation' to the Jewish community for the shortcomings of the recently installed memorial at the Neue Wache (the former Prussian 'New Guardhouse') on Unter den Linden in downtown Berlin. This site was criticized as an inappropriate symbol for the Jewish victims, with its Pieta-like sculpture by Käthe Kollwitz at its center, plus its vague reference to the victims of tyranny ('Gewaltherrschaft'). But the current Holocaust memorial has in turn led to questions about how to represent the non-Jewish victims: e.g. homosexuals, Gypsies (Sinti and Roma) (Meier, 1998; Wise, 1998: 145). 
design competition in 1994-5 resulted in 528 entries, with the winning entry from a Berlin artists' collective, led by Christine Jackob-Marks. It was a formidable design: an inclined concrete tombstone, 23 feet thick, covering nearly the entire 5-acre block. It would have vaguely resembled a horizontal version, greatly enlarged, of Maya Lin's Vietnam War Memorial in Washington, with the names of 4.2 million known Jewish Holocaust victims inscribed there. ${ }^{2}$

Opposition to the enormous scale and the cenotaph-like design was both swift and severe and led to a veto by Chancellor Helmut Kohl, to the relief of many Germans who had dreaded having such a bleak, massive tombstone permanently at the heart of the newly unified capital city. A revised architectural competition led to four finalists by early 1998, with the ultimate winner to be selected by the federal government, the city government, and a private organization founded by the journalist Lea Rosh, who had originally promoted the monument (Deutschland Nachrichten, 1998a; 1998b). Leading the four finalists is the design by the American team of sculptor Richard Serra and architect Peter Eisenman, who have proposed a monumental field of columns. Their design has received the support of Chancellor Kohl, though the final decision has been delayed again (as of October 1998).

Yet the debate has also shifted from the question of which design is most appropriate to a larger question of whether any design is appropriate — particularly for a project that is an abstract aesthetic statement on a fabricated site, rather than the preservation or reproduction of a historic Nazi site (such as the camps). There are increasing calls to further postpone the selection or cancel the project entirely. In February 1998, Günter Grass, Marion Gräfin Dönhoff, Peter Schneider and other prominent Germans issued an open letter in opposition to the memorial: 'We don't see how an oppressive, abstract installation of such enormous proportions on a field the size of the sport stadium could create a place of quiet mourning and memory, reminder or meaningful enlightenment' (Deutschland Nachrichten, 1998a). Increasing opposition came from other circles as well, including the leader of the Berlin Jewish Community and the city mayor (Andrews, 1998; Der Tagesspiegel, 1998a; 1998b). Even the future Social Democratic (SPD) chancellor, Gerhard Schröder, spoke out in opposition to the monument (and thus to Helmut Kohl's position) while campaigning this past July.

Marcuse's own memorial proposal, suggested in passing, is an interesting 'antimemorial': to 'leave the site barren and weed-overgrown, with merely a sign: 'This is the location at which a monument to the murdered Jews of Europe was to have been erected. Because an understanding of what led those who murdered them to act as they did has not yet been achieved, the site remains barren' (Marcuse, 1998: 336). Though Marcuse does not actually advocate erecting such a design, the idea is both insightful and revealing: that a definitive, large scale, government-sanctioned, abstract aesthetic statement on the Holocaust may be more concealing than revealing.

This task of artistically representing the Holocaust is a tricky affair. Historic events and their aesthetic representation are ultimately irreconcilable, making an 'historically accurate' monument both a moral necessity and an impossibility. Efforts to explain and document the Holocaust in postwar Germany have been precariously balanced between

2 The test of a successful monument is not (simply) the degree of accuracy in its representation of a historical period, but rather the larger effect of the monument on the nation's discussion and reflection about the event. The success of the Vietnam War Memorial in Washington, DC is a compelling example of why monuments cannot be seen in aesthetic isolation, but rather in their social context: how they are used and understood. Its partially submerged $v$-shaped stone surface is not necessarily an accurate reflection of the war, and yet the monument, infused with social meaning by all the engaged visitors, surviving veterans and family members, has brought about a thoughtful national debate and discussion. It is more difficult to envision the various Holocaust memorial designs in Berlin serving the same function, perhaps because the Germans will not identify with the Jewish victims in the same way that Washington tourists identify with the names of the dead American soldiers engraved in stone. 
the dangers of underprocessing and overprocessing. The more obvious postwar danger has been to underprocess: to neglect, avoid, deny or relativize the Nazi past, thereby distancing the Germans from responsibility. But there has also been an opposite danger: to develop an overly rational, tidy explanation of the Holocaust that, ironically, also leads to a marginalization of responsibility. The East German state was prone to this latter habit, explaining away the rise of Nazism as the by-product of monopoly capitalism. East Germans could thereby deductively avoid any kinship to the Nazis, since their state socialist system - as opposed to the national socialist one - was structurally, inherently unable to lead to fascism.

This is one way to understand Marcuse's skepticism: that the overprocessing of the Holocaust will make it marginal, which paradoxically has the same effect as neglecting it. More broadly, there is the underlying fear that a perfect Holocaust memorial would signal two fundamental transformations: first, that the Holocaust can be completely comprehended; and second, that the memorial represents a final atonement for the crimes of the German nation. Marcuse's idea of an unfinished monument is a call for the national debate on Nazism to remain open, alive, unresolved. Amidst the construction cranes and new entrepreneurialism and arriving bureaucrats from Bonn, there is a heightened fear that this new myopic capital city will be too busy running the bureaucracy and making money to stop and ponder the larger German questions.

Thus, the opposition to a top-down, nationally-sanctioned Holocaust memorial contains an unspoken fear that the monument marks the end of Germany's postwar period of reflection and confrontation with its past (Vergangenheitsbewältigung). A decade earlier, this misgiving also fueled the antagonism in the 'historians debate' (Historikerstreit): that in relativizing the Holocaust, the Germans were in effect rejecting the uniqueness of the Holocaust, placing it in its historical context, and saying it is time to move on. This mistrust resurfaced again in the wake of German unification in 1990, with the end of probationary-like Allied occupation of Berlin suggesting to some that Germany was now fully ready to move out from under the guilt-ridden shadow of Hitler. For some, to stop short of a definitive, government-approved Holocaust memorial is to also stop short of completely forgiving the Germans. As long as the monument remains incomplete, the debate is still open, and the atonement still continues. In the end, for many people the Holocaust memorial debate may be a moot point, since no matter what the Germans do or say, no matter what their monuments are, the world will never fully forgive them for the Holocaust.

For many voices in the Holocaust memorial debate, the central question is how and whether one can appropriately represent this historic event aesthetically on a city block in downtown Berlin. What is distinctive about Marcuse's argument is that he criticizes this preoccupation with form as too limited and instead shifts the attention toward the larger political and economic functions of the new capital. It is Berlin's landscape of power, not its landscape of aesthetics, that most troubles Marcuse. A preoccupation with the latter tends to 'lapse, suppress and conceal deeper issues of responsibility and current policy' (Marcuse, 1998: 337). For Marcuse, the emerging landscape in Berlin reflects a troubling reconcentration of business and political power. This observation leads him to the most controversial argument of his article: that the real danger is a return to a kind of politicaleconomic landscape that is reminiscent of Germany 60 years ago. 'Does not history teach the dangers of a strong centralized state intertwined with a strong centralized private economy, certainly, if not only, in Germany?' (Marcuse, 1998: 333).

In this light, Marcuse sees the greatest benefit of any future Holocaust memorial not as an encapsulation of the past, but instead as a warning for the future 'against the consequences of that power and wealth in the hands of an arrogant and asocial state and business community...' (Marcuse, 1998: 337). The great contradiction of the memorial for Marcuse is that it ostensibly promotes moral values that are being rejected by the new capitalist boom economy landscape around it. 'Power and murder were historically 
intimately linked in Nazi Germany; one cannot now celebrate the former at the same time as one mourns the latter. No matter how one designs a Holocaust memorial, in the shadow of the new Regierungsviertel [government quarter], Potsdamer Platz [the location of new Daimler-Benz and Sony high-rises], and Friedrichstraße [a luxury shopping street], the meaning of the memorial turns into its opposite, into a final laying to rest rather than a living provocation, as long as power and wealth march on undisturbed all around it' (Marcuse, 1998: 337).

Marcuse does not directly come out and state that the modern-day German Federal Republic poses the same threat as did the Third Reich. (And any such literal comparison would be highly dubious.) What he does compare, at times in a roundabout way, is the current reconcentration of political-economic power in Berlin with a seemingly similar pattern in the past.

It is true that Berlin is currently experiencing a building boom, making room both for the return of national government employees in 1999 and for an anticipated economic revitalization of Central Europe's formerly dominant economic metropolis. It is also true that the city is shedding some of the modesty and hesitation that were adaptive behaviors of the cold-war period of division. Yet contemporary Berlin is fundamentally different from Nazi Berlin. Berlin was once an imperial capital with a strong military-industrial complex and was the economic capital as well. Present-day Berlin will be the capital of a decentralized federal government, with far greater institutional separation between the political, the economic and the military than was found in imperial Berlin (or in communist East Berlin). Germany has also developed a successful, spatially decentralized economic network of cities, and Berlin will not be able to dominate the financial, industrial or information sectors of Germany (and certainly not of a unifying Europe). The spatial division of political and economic power between the cold-war capital in Bonn and the major economic centers in Frankfurt, Hamburg, Munich and elsewhere (like the spatial division of power between Washington, DC and New York) reflects this new postwar arrangement in Germany. Over 50 years ago, the occupying Allied forces directly addressed this fear of imperial Germany's centralization of power and wealth as fuel for the Nazi war machine through the explicit decartelization of the defeated nation: both of political power (divided occupation and a federal structure for West German government) and business (the breaking up of large industrial interests such as I.G. Farben and the loss of international subsidiaries and patents). Today, the increasing integration of Germany into the political, military and economic networks in Europe has further distanced Germany - and thus Berlin — from its prewar nationalist-imperial structure.

Over a century ago, Berlin was the high-profile center of aggressive nation-building following several Prussian military victories in 1866-71. A half-century ago, Bonn was the low-profile center of national atonement and rebuilding following military defeat and Allied occupation in 1945. The Berlin of today is a new kind of capital, for the first time building a German nation not following a hot war, but rather a 'peaceful revolution'. It is therefore neither the heroic nationalism of military conquest, nor the shameful retrenchment of defeat, but rather the atmosphere of east-west integration that offers the promise for the capital city. This is not to say that the current redevelopment of Berlin is beyond criticism: there is a troubling 'schizophrenia' of boomtown and recession, a lack of a clear planning vision to coordinate and regulate the 1990s building boom, greater tolerance of rich-poor disparities, intolerance of immigrants, a rising interest in right-wing politics, and enduring resentment and inequality between east and west. In other words, Berlin is becoming a western capitalist city like many others.

Marcuse's wariness towards Berlin's current capitalist redevelopment embodies a well-argued, perhaps unavoidable criticism. His article also contains a certain nostalgia for a Berlin that is now vanishing under construction cranes, gentrification and the invasion of bureaucrats from Bonn. It is not a literal nostalgia for the cold-war nonidentical twins of a subsidized island economy of West Berlin and an oddly small-town- 
like, overly earnest and gray East Berlin. Instead, it is a trepidation that the physical reconstruction of Berlin is also a social and ideological one: that a sanitized, revisionist, investment-friendly Berlin will displace a cold-war Berlin whose history, like its monuments and buildings, was rough-edged, thought-provoking, incomplete and openended (like the anti-memorial suggested by Marcuse). Some miss West Berlin's paradoxically snug insularity with its overabundant arts institutions, night life, leftist alternative scene, exemption from Bundeswehr conscription and protection from market forces, all underwritten by federal revenues from the postwar West German economic miracle. Others even miss the slower paced life, the security of social services and the oases of community found in communist East Berlin. Marcuse himself laments the possible demolition of the former Palace of the Republic because it symbolized 'the priority of public space and public life over the private' (Marcuse, 1998: 335) in East Berlin (though I would suspect that the source of the building's popularity was more prosaic, due as much to its multiple restaurants in a town with a chronic shortage of available dining).

Marcuse is thus not alone in this lament for the loss of some strangely humane, introspective qualities found in cold-war, divided Berlin. But that Berlin is unavoidably vanishing: both sides of the wall were unreal front cities, heavily subsidized and protected from international economic competition to serve the larger ideological needs of their respective national states. This cold war arrangement was inherently transient and not sustainable in the long run.

Berlin is now struggling to redefine its urban role after years of its dual identity as front city and socialist capital. It is currently facing the growth pains of a city that strives to become a global city on a par with London and Frankfurt, yet is hesitant to give up its more provincial local government tendencies and its dependence on generous cold-war subsidies. It is a city that for years has hoped to capitalize on becoming the economic gateway to the eastern European markets, while fearing that east-west trade will simply leapfrog over Berlin. It is also a city that is desperately hoping that the arrival of the national government from Bonn next year will prove to be the local economic growth catalyst that it was before the war, while fearing that the decentralized, federated, postimperial Germany no longer needs or wants an economically powerful capital (as the 50 years of administration from unassuming Bonn suggest). Overall, it is a city with contradictory aspirations and expectations, unsure of how to both capitalize on and distance itself from its own past. No wonder, then, that the task of designing a downtown city block, located between old imperial structures and new corporate high-rises, to define the city's relationship to the Holocaust has become an intractable task. However, the current stalemate over the monument need not be seen as a damning failure of either Berlin's local politics or Germany's confrontation with its Nazi past, but rather as an outcome of a more universal disparity between art, historical events and political consensus.

It is unclear what alternative development scenario Marcuse envisions for modern Berlin. In 1989, there was a short-lived hope that Berlin (and East Germany in general) could go down a 'third path' between western capitalism and German Democratic Republic socialism. Yet in the end, this third path was neither plausible or even legitimate. It may have been nothing more than an unwillingness to change, to accept the failure of the socialist experiment of the GDR (Schneider, 1991: 89). At worst, it was merely an unrealistic wish to 'have one's cake and eat it too' — to enjoy both the freedoms of democratic free markets and the security of state socialism. Even in West Berlin, which has suffered far less disruption and displacement than the east, there has been a similar contradictory hope of maintaining the insular benefits of a front city (such as unusually inexpensive rents, subsidized incomes, excess infrastructural capacity and a distinctive local political culture) while striving to become a competitive global city economy. The current irony is that Berlin seems to have achieved neither goal, having 
lost a great deal of neighborhood identity and control over urban development while having so far failed in its strategy to become a European advanced service center (Strom and Mayer, 1998).

In the foreseeable future, the city will become neither an alternative model of a cooperative-democratic urban political economy nor a juggernaut of reawakened German nationalist power. That is, Berlin will likely not become as lofty a city as some have hoped, nor as dangerous as others have feared. Instead, as the cold-war era fades, Berlin will gradually lose its unique identity and function, becoming increasingly assimilated into the political-economic network of European cities. For some, this urban Euroconvergence will evoke a nostalgia for the bizarre lost landscapes of Berlin's extraordinary past. But arguably for more, this assimilation will be reassuring.

Scott Campbell (sdcamp@umich.edu), Urban and Regional Planning Program, College of Architecture and Urban Planning, University of Michigan, Ann Arbor, MI 48109-2069, USA.

\section{References}

Andrews, E.L. (1998) Serra quits Berlin's Holocaust memorial project. The New York Times 4 June, E1.

Der Tagesspiegel (1998a) Brauchen wir wieder Utopien, Herr Sennett? 6 May.

— (1998b) Jüdische Gemeinde für Denkpause in der Mahnmal-Debatte. 15 April.

Deutschland Nachrichten (1998a) Auf Holocaust-Denkmal verzichten? 6 February, 6.

— (1998b) Holocaust Denkmal: Serra zieht sich zurück. 5 June, 6.

Kernke, S. (1998) Entscheidung über Holocaust-Denkmal verschoben. Deutschland Nachrichten 11 September, 6.

Kramer, J. (1995) Letter from Germany: the politics of memory. The New Yorker 14 August, 48 65.

Marcuse, P. (1998) Reflections on Berlin: the meaning of construction and the construction of meaning. International Journal of Urban and Regional Research 22.2, 331-8.

Meier, C. (1998) Kein Machtwort. Der Tagesspiegel 19 June.

Schneider, P. (1991) The German comedy: scenes of life after the wall. Farrar, Straus and Giroux, New York.

Strom, E. and M. Mayer (1998) The new Berlin. German Politics and Society.

Wise, M.Z. (1998) Capital dilemma: Germany's search for a new architecture of democracy. Princeton Architectural Press, New York. 